\title{
Històries escrites, històries cantades i històries pintades. Els goigs en el Barroc valencià
}

\author{
Writing stories, sung stories and painted stories.The goigs in the \\ Valencian Baroque \\ JoAn- Carles Gomis Corell \\ joan.c.gomis@uv.es \\ Conservatori Superior de Música de Castelló - ISEACV
}

\begin{abstract}
Resum: A partir de principis de la setzena centúria, la implantació de la impremta i el consegüent afermament de la tradició escrita propiciaren que els goigs iniciaren, particularment a València, un progressiu procés de difusió. El nou invent facilitava incloure a l'estampació la reproducció de la imatge sagrada a la qual anava dedicada la composició, de manera que, a més de transmetre el text de l'oració, assoliren el valor i funció d'estampes devocionals. No inclö̈en, però, la música, la qual cosa indicaria que hagué de quedar fiada a la memòria i bon fer interpretatiu dels cantors de les capelles musicals. La posterior implantació dels postulats contrareformistes afavorí la difusió i popularització dels goigs, que culminà en la segona mitat del segle XVIII, quan la religiositat barroca fou qüestionada pels nous postulats il lustrats. Els texts, de la lloança i invitació a la meditació pròpies del segle XVI, es transformaren majorment en peticions de favors i en històries narratives d'aparicions, troballes d'imatges i esdeveniments miraculosos, carregats de teatralitat i efectisme. L'Església contrareformista va veure en els goigs un bon mitjà per a exalçar els personatges sagrats i estimular la pietat dels fidels sense deslligar-se de la tradició literària de les hagiografies cultes. Els goigs passaren a ésser versions reduïdes d'aquest gènere literari, i també de les "vertaderes històries", fent properes i comprensibles als fidels, gràcies a l'oralitat que els conferia el cant, les històries escrites, les quals, a la vegada, servien als pintors per a compondre llurs històries pintades.
\end{abstract}

Paraules clau: goigs, Barroc, Contrareforma, València, festa.

\begin{abstract}
From the beginning of the sixteenth century, the implantation of the printing press and the consequent affirmation of the written tradition caused that the goigs initiated, particularly in Valencia, a progressive diffusion process. The new invention facilitated the reproduction of the sacred image to which the composition was dedicated, so that, in addition to transmitting the text of the prayer, they achieved the value and function of devotional prints. They did not include, however, music, which would indicate that it had to be trusted to the memory and good performing of the singers of the musical chapels. The subsequent implantation of the counterreformist postulates favoured the dissemination and popularization of goigs, which culminated in the second half of the 18th century, when Baroque religiosity was questioned by the new illustrated postulates. The texts, from the praise and invitation to meditation typical of the 16 th century, were mainly transformed into requests for favours and narrative stories of appearances, finding images and miraculous events, full of theatricality and effect. The counter-reform Church saw in goigs a good way to exalt sacred characters and stimulate the piety of the faithful without getting rid of the literary tradition of cult hagiographies. Goigs happened to be small versions of this literary genre, as well as of the "true stories", making them understandable to the faithful, thanks to the orality conferred by singing, written stories, which, at the same time, they served the painters to compose their painted stories.
\end{abstract}

Keywords: catalan syntax, linguistic variation, diachronic linguistics, semantic change. 
Joan Carles Gomis Corell. Històries escrites, històries cantades i històries pintades. Els goigs en el Barroc valencià

\section{Introducció}

Des de ben antic, la música ha confluiit amb unes altres arts. Tatarkiewich (1976/1997: 157-160, 255) plantejà la possibilitat que a Grècia la symmetria de l'arquitectura i de l'escultura derivara de l'harmonia musical, concebuda aquesta com a un sistema de quantitats geomètriques expressades aritmèticament. Haguera o no estat així, els grecs, si més no, feren confluir la música amb l'estructura del llenguatge. Aquesta analogia -de possible origen pitagòric, citada per Plató (República 398d) i desenvolupada per Aristoxé (Harmónica 27, Rítmica 9) - ${ }^{1}$ fou transmesa al món llatí per la traducció i el comentari de Calcidi al Timeu. ${ }^{2}$ Recuperada a final del segle IX per Musica enchiriadis i madurada per Guido d'Arezzo, qui, a més, la posà en relació amb el discurs poètic - «el compositor, igual que el poeta, ha de construir l'obra musical mitjançant seccions homogènies quant a l'amplitud i nombre d'elements» (Micrologus, XV)-, acabà essent principi regulador de la polifonia de l'Ars antiqua: com diu l'Anònim de Sant Emeran, «la musica mesurabilis s'anomena així per la mesura de les notes, com en la gramàtica la mètrica rep el mateix nom per la mesura de les síl labes (...)».

Foren aquestes confluències o analogies trasbalsaments tècnics amb la pretensió d'obtenir regles precises que, comprovada llur efectivitat en una art, pogueren aplicar-se al procés compositiu d'una altra amb garantia de correcció. En el Barroc, però, aquelles confluències foren més comunicatives i emotives, si bé les arts, gràcies a la correcció compositiva, ho havia advertit en el Renaixement Leon Battista Alberti (De re aedificatoria I, 8) posant com a exemple la música, «captiven l'esperit i (...) mouen i posseeixen l'ànim.» Aquest valor commovedor de l'ànim va ser el que es demanà essencialment a les arts durant el Barroc, amb la pretensió de suscitar una sensualitat - fins i tot, una irracionalitat- que convencera més pels sentits que no pas per la raó. Aquesta era un dels components de la subjectivitat; l'altre eren les passions. La música es subordinà al propòsit d'excitar les passions, rescatant però la paraula, el logos, per quant té de racionalitat i poder de comunicació conceptual i narrativa. Si hom hi sumava la capacitat de compendiar una història que s'atribuïa a la imatge equiparant-la a la poesia -Utpictura poesis fou un dels tòpics de la teoria artística del Barroc-, l'efectivitat comunicativa quedava garantida.

\section{El valor dels goigs en el Barroc}

Uns dels primers goigs valencians coneguts els escriví el 1464 Joan de Campos, notari de la ciutat de València, en la coberta d'un notal. Dedicats, com és propi dels inicis del gènere, a la lloança dels set goigs terrenals de la Mare de Déu -«Perquè ven planet vos sia / mare del meu crehedor, /cantaré ab gran amor / vostres goigs, Senyora mya (...)»-, degueren ésser una mena d'oració privada que guiara i garantira el treball ben fet. $^{3}$

1 Cf. Arístides Quintiliano, De musica I 20-23.

2 Sobre la recepció de Calcidi en l’època carolíngia vid. Huglo M. (2005: IV, 3-20).

3 Arxiu del Regne de València, Protocols, Notal de Joan de Campos, 2528, f. 1r.; amb una petició ben concreta, que el

SCRIPTA, Revista internacional de literatura i cultura medieval i moderna, núm. 11/juny 2018/pp. 131-158

ISSN: 2340 - 4841 doi:10.7203/SCRIPTA.11.12589 
Joan Carles Gomis Corell. Històries escrites, històries cantades i històries pintades. Els goigs en el Barroc valencià

Continuaren el goigs durant el Barroc tenint aquell valor de pregària individual. Fra Gaspar Bono emprava el temps lliure que li deixaven les diverses ocupacions de la vida conventual «(...) en oración, en leer libros devotos, cantar algunas alabanzas a los santos (que comúnmente llamamos gozos) y rezarles varias devociones, pues tenías muchas. Los loores o gozos se les oían cantar los que passavan por el dormitorio (...)» (Ortí y Mayor 1750: 73). Ara bé, mentre que els goigs de les darreries del segle XV i de la primera mitat del XVI, inspirats per la devotio moderna i el mètode devocionalista de meditació sobre els misteris de la religió, units a l'afectivitat franciscana, interpel laven el lector o el cantor i el convidaven a la contemplació - «Contemplau ab pensa pia /cristians la soledat /que sentí l’ànima mia /quan Jesús fon sepultat (...)», comencen Les cobles de la Verge Maria de la Soledat-, ${ }^{4}$ els goigs barrocs sol licitaven del cel l'obtenció de favors. El franciscà Pere Esteve compongué goigs a la imatge de sant Pere Cap de Pals «(...) para mayor comodidad y devozión de los suplicantes (...)», i uns altres a la Mare de Déu sota la invocació de la Muntanya de Santedat per ésser «(...) mucha la frequencia con que todos hazían sus oraciones y rogativas $(. .$.$) y conseguían por su intercessión varios remedios en sus males (...)» (Mercader$ 1677: 93, 97). ${ }^{5}$

Assumiren els goigs el dictamen del Concili de Trento sobre la licitud de recórrer a la intercessió i l'auxili dels sants i de les imatges sagrades per atènyer els beneficis de Déu (López de Ayala 1787: 356). Com canten els Goigs de Nostra Senyora dels Desamparats, ${ }^{6}$ composts segurament quan el certamen literari del 9 de maig del 1667 celebrat a la ciutat de València pel trasllat de la imatge a la nova capella, aquells beneficis i emparaments es feren extensius als diversos àmbits de la vida quotidiana: treball, llibertat per als empresonats, malalties, parts i particularment alliberadora «de pestilència / y enfermetat contagiosa (...)», per tal com s'havia atribuït a la seua intercessió el cessament de la pesta del 1647 (Ortí y Mayor 1767: 118). ${ }^{7}$ La intercessió de la Mare de Déu es

tragués de la presó on l'havia reclòs el bisbe d’Urgell, el també notari d’Igualada Huguet de Serrallonga escrigué el 1448 una pregària a la Mare de Déu en forma de dansa amb una introducció de quatre versos i quatre estrofes de vuit, tots heptasíl labs (De Courcelles 2008: 205-206).

4 [Ortigues, Miquel?] (1510?) Cobles de la Verge Maria de la Soledat, ab l'Ave maris stella en pla, s. ll. [València], s. i., s. a., Universitat de València, BH CF/4 (14).

5 En general sobre l'obra literària en valencià de fra Pere Esteve vid. Escartí (2005).

6 Goigs de Nostra Senyora dels Desamparats (s. 1l., s. i., s. a.: València, ca. 1740-1760), Universitat de València, BH Ms. 0870 (036). No coneixem constància explícita del cant d'aquests goigs. Ortí y Mayor (1767: 114-115) només diu que el dia de la festa de la Mare de Déu dels Desemparats «(...) se celebra la missa con mucha y sonora música (...). Sigue después el novenario en la capilla, por la mañana con missa solemne y por la tarde, después del sermón y novena, se reza el Rosario, con la assistencia de la música de la Iglesia Mayor».

7 Fra Pere Esteve, però, atribuí el final de la pesta a la imatge de la Mare de Déu de la Muntanya de Santedat, com diu la darrera cobla dels goigs que ell mateix compongué (Mercader 1677: 100-101):

(...)Lo malalt y abribulat

vos crida per advocada,

y València ya curada

SCRIPTA, Revista internacional de literatura i cultura medieval i moderna, núm. 11/juny 2018/pp. 131-158

ISSN: 2340 - 4841 doi:10.7203/SCRIPTA.11.12589 
Joan Carles Gomis Corell. Històries escrites, històries cantades i històries pintades. Els goigs en el Barroc valencià

restringia, però, als fidels que la «(...) criden humillats $(. .)$.$» , proclamant literalment aquests goigs$ la condició que el Concili de Trento havia imposat a la invocació de sants, relíquies i imatges: «bono atque utile esse suppliciter eos invocare» (López de Ayala 1785: 356).

Havia decretat també aquell concili que calia instruir convenientment els fidels quant a la invocació i l'ús de les imatges (López de Ayala 1787: 355). Com a conseqüència, es generà una sèrie d'obres que, com hem dit en altres ocasions, constituïren el gènere «de les vertaderes històries d'imatges» (Gomis Corell 2015: 139-147). La primera, tant a València com al conjunt de territoris hispans, en fou la Historia de la adoración y uso de las santas imágenes, y de la imagen de la Fuente de la Salud, obra de Jaume Prades, doctor en Teologia i rector d'Ares, feta «(...) conforme ordena la Iglesia que lo hagan sus ministros, porque no yerre el pueblo en esta verdad por falta de dotrina, sino que tenga della noticia conveniente» (Prades 1596: 4). ${ }^{8}$ És a dir, amb finalitat didàctica, catequètica fins $i$ tot. Aquestes obres -açò les diferencia de les col leccions de miracles i vides medievalsvolgueren legitimar l'autenticitat i la veneració de les imatges sagrades aportant i contrastant amb més o menys rigor referències documentals i informacions d'altres autors anteriors. Aquest caràcter historicodocumental produí doctes i llargues narracions escrites, pràcticament totes en castellà, farcides a més de cites erudites, algunes transcrites directament en llatí. En conseqüència i en paral lel a les dites obres, els goigs afegiren a llur primer valor d'oració i d'elogi la finalitat de corroborar i propagar amplament entre els fidels la pretesa veracitat històrica de les troballes i aparicions portentoses de diverses imatges sagrades, sobretot marianes. Les llegendes tradicionals traslladades als goigs atenyeren igualment validesa testimonial i, una vegada escrites, també documental. Fra Agustín Bella, cronista de la Província Agustina de València, quan el 1714 escrigué la Verdadera relación de la invención de la imagen de Maria Santíssima de Aguas Vivas (Libro de la donación....: 132v.), no dubtà en cap moment que:

(...) la inmemorial tradición del convento se manifiesta en los loores o gozos que se cantan a

María santíssima en esta su sagrada imagen, que en nuestra lengua materna dise:

El trobar-os fon a cas puix és tradició molt vella, que la punta de una rella

llaurant os tocà en lo nas;

el señal d'ell corrobora esta història celebrada, \&. (...)

vos fa gràcies de bon grat;

té ya per vós sanitat

y del contagi sanada,

de les gents intitulada

Montanya de Santitat. (...)

8 Sobre aquest tractat vid. Velandia Onofre (2017: 185-194).

SCRIPTA, Revista internacional de literatura i cultura medieval i moderna, núm. 11/juny 2018/pp. 131-158 ISSN: 2340 - 4841 doi:10.7203/SCRIPTA.11.12589 
Y siendo la tradición de tanta fuerça y valor como los historiadores saben, no nos podemos apartar de ella quando nos faltan instrumentos auténticos de aquellos tiempos que nos digan lo contrario.

En una societat majoritàriament analfabeta, els goigs foren molt més eficaços per garantir als fidels la veracitat d'aquelles històries llegendàries. També es lliuraven a la impremta, però no eren per a llegir, sinó per a ésser proclamats mitjançant el cant en processons, rogatives, novenaris i diverses altres celebracions festivoreligioses, tan abundants i freqüents en la societat barroca. En una València molt castellanitzada literàriament des de la segona mitat del segle XVI, els goigs romangueren fidels a la llengua del país -si més no al llarg de tota la dissetena centúria-, motiu pel qual resultaren més emotius -fra Gaspar Bono cantava els goigs de sant Vicent Ferrer «(...) en nuestro materno idioma, por excitarle más a devoción (...)» (Ortí y Mayor 1750: 42)-i, sobretot, més comprensibles, ja que, a més, compendiaven en pocs versos les mateixes històries que narraven les llargues i documentades obres de canonges, pabordes, frares i preveres.

Així, els Goigs de Nostra Senyora del Puig, atribuïts al mercedari fra Damià Esteve, concentren en la vuitena cobla tot el que, si més no des de Beuter (1538: 48v., 1551: 180-181), n’havien escrit en castellà els diversos historiadors i cronistes (Prades 1596: 96; Bleda 1618: 438):

$$
\begin{aligned}
& (. . .) \text { Les esteles veu Nolasco } \\
& \text { y en la campana os trovà, } \\
& \text { torre contra el infel Damasco } \\
& \text { que mà de àngels fabricà }(. . .)^{10}
\end{aligned}
$$

Quatre versos foren suficients per a transformar-ne la llegenda en història. Tingueren més efectivitat aquests goigs que no pas la coetània i eixerida obra Nuestra Señora del Puche, cámara angélica de María

9 Són, sens dubte, goigs del segle xviI, ja que en un document del 1666 referent a la festa de la Mare de Déu d'Aigües Vives s’anota que «todos los sábados, Salve y Gozos se cantan» (Libro de la donación...: 57r.). Llur autor fou, amb pràcticament total seguretat, fra Agostí Casanova, prior del convent d'Aigües Vives el 1627 (Fogués 1982, 101), per tal com fra Agustín Bella (Libro de la donación .... 132r.-v.) diu seguir «(...) una relación manuscrita que hallé entre los papeles del depósito del convento hecha por el padre lector jubilado fra Ang[ustín] Casanoves, que todos conocimos y poco tiempo ha que murió». La publicació més antiga que se'n coneix és, però, del 1748, i clou el Compendio del feliz hallazgo de la milagrosíssima imagen de la Virgen de Aguas Vivas (Pérez 1748: 84-86). Les estampacions en fulls solts hi són posteriors: Gochs a Nostra Señora de Aygües Vives, venerada en el convent de agustinos de la vila de Carcaixent, s. 11., s. i. s. a [València, Agustín Laborda, ca. 1770], Universitat de València, BH CGV/020; Goigs a Nostra Senyora de Aygues Vives, venerada en lo convent de agustinos de la vila de Carcaixent, Valencia, Viuda de Agustín Laborda, 1803, Universitat de València, BH Ms. 0870 (145).

10 Goigs de Nostra Senyora del Puig, patrona principal de la ciutat y regne de València, venerada baix lo titol dels Àngels, s. ll., s. i., s. a. [València: impremta de Laborda, ca. 1750-1780], Universitat de València, BH Ms. 0870 (146). L'atribució a fra Damià Esteve figura en algunes estampacions decimonòniques d'aquests goigs (Genovés y Olmos 1911: III, 194-195). No la refereixen Fuster (1827: I, 276) ni Ximeno (1747: II, 114-115); no citen cap obra de fra Damià Esteve Rodríguez (1747) ni Puig Torralba i Martí Grajales (1883). Almarche (1917: 120) els situa a les darreries del segle XVI, amb la qual cosa no els considera obra de Damià Esteve, el qui visqué en la centúria següent. Ara bé, les característiques de la llengua -tot i que el text pogué haver sofert diverses intervencions fins al moment de la impressió-, amb castellanismes evidents -amaneixqué, ausència, ausenta, después-i l'estructura musical de la melodia no permeten situar-los -creiem-més enrere de la segona mitat de la dissetena centúria. 
Joan Carles Gomis Corell. Històries escrites, històries cantades i històries pintades. Els goigs en el Barroc valencià

Santíssima, patrona de la insigne Ciudady Reyno de Valencia. Monasterio Real del orden de redentores de Nuestra Señora de la Merced, fundación de los reyes de Aragón, escrita el 1631 pel també mercedari Francisco Boil. Pretenia l'autor amb aquesta obra «renovar la memoria de un santuario célebre en la antigüedad, porque no pierda de famoso» (Boyl 1631: 1), per tal com la invocació mariana dels Desemparats estava desplaçant la del Puig en la religiositat valenciana. No aconseguí, però, el seu propòsit: el patronatge de la Mare de Déu dels Desemparats es retrotragué fins al moment de la conquesta cristiana, assimilant la invocació a la del Puig: «(...) desde su conquista tuvo [València] la dicha de lograros por patrona, aunque con la invocación del Puche» (Ortí y Mayor 1767: IIv.). Els goigs, si més no, continuen cantant-se en l'actualitat (Gomis Corell 1999b: $187-$ 188; 2011: II, 401-420).

Diversos altres goigs amb històries de troballes i aparicions d'imatges i diversos miracles ocorreguts per llur intercessió es compongueren més o menys coetàniament als respectius relats cultes: els Gozos a Nuestra Señora la Virgen de la Cueva Santa, la història de la qual havia escrit el jesuïta José de la Justicia (1664); $;^{11}$ els Goigs de la Verge de la Assumpció, en la vila de Elig, els Gozos a Nuestra Señora del Populo de Quart de les Valls i els Gozos a Nuestra Señora del Don, venerada en el lugar de Alfafar, les històries de les quals, entre moltes altres, recull Dolz de Castelar (1686/1733: III, 182, IV, 214-215, 399); ${ }^{12}$ els Goros a Nuestra Señora de Campanar, inclosos al final de l'obra de Bartolomé Combes (1714: 249-259), rector d'aquella parròquia, o els dedicats als Crist de Sumacàrcer, en paral lel a la primera història d'aquesta imatge, Maravillas del poder divino, en el Santísimo Christo de Sumacárcel, de mossèn Pedro Selva, rector de la parròquia entre el 1700 i el $1718 .{ }^{13}$ La progressiva castellanització de la societat valenciana provocà que des del principi del segle XVIII també els diversos autors abandonaren de forma pràcticament absoluta com a llengua poètica dels goigs la pròpia del país. La gran quantitat d'impresos conservats ho constaten, i és ben significatiu que Ortí y Mayor (1750: 153) especifique que, d'entre tots els goigs que fra Gaspar Bono cantava -a sant Vicent màrtir, a sant Valer, a sant Cristòfol, a santa Agnés, a santa Anna, etc.- només «(...) a san Vicente Ferrer le cantava, puesto de rodillas, sus gozos en lengua valenciana». ${ }^{14}$

11 Gozos a Nuestra Señora la V irgen de la Cueva Santa, s. ll., s. i., s. a. [València, ca. 1750-1760], Universitat de València, BH CGV/045.

12 Goigs de la Verge de la Assumpció, en la vila de Elig, València, José Estevan, s. a. [entre 1760-1776]. Ribelles Comín (1939: III, 26) diu haver-ne vist un imprés de mitjan segle xvII; Gozos a Nuestra Señora del Populo, hallada en las ruinas de una pared, en la baronia de Quart (...), Valencia, Salvador Faulí, 1770; Gozos a Nuestra Señora del Don, venerada en el lugar de Alfafar, Valencia: Joseph García, s. a. [ca. 1725-1765], Universitat de València, BH Ms. 828 [De Orellana, M. A. (recop.)]: Gozos de Nuestra Señora con varias invocaciones, f. 335, núm. en tinta negra 172, núm. en grafit 314. Per a una anàlisi d'aquests goigs vid. Gomis Corell (2010: 143-169).

13 Gozos al Santíssimo Christo de Sumacárcel, s. 11., s. i., s. a. [València, ca. 1750-1760], Sumacàrcer, Parròquia de Sant Nicolau de Bari; Gozos del Santo Christo de Sumacárcel, s. 1l., s. i., s. a. [València, ca. 1768-1790], Universitat de València, BH Ms. 804 [Borull, F. J., Gozos a los Santos y Santas], full núm. 19; Ms. 0870 (204).

14 Ortí y Mayor es referia als Llaors del gloriós e benaventurat sent Vicent Ferrer, patró e fill de la insigne ciutat de València,

SCRIPTA, Revista internacional de literatura i cultura medieval i moderna, núm. 11/juny 2018/pp. 131-158

ISSN: 2340 - 4841 doi:10.7203/SCRIPTA.11.12589 
Joan Carles Gomis Corell. Històries escrites, històries cantades i històries pintades. Els goigs en el Barroc valencià

També havia decretat el Concili de Trento que era lícit recórrer als sants i màrtirs per aconseguir els beneficis de Déu, i sobretot que llurs vides havien de servir d'exemple de comportament per als fidels (López de Ayala 1785: 356). Novament els goigs foren mitjà adient per mostrar eficaçment els models dels sants i els beneficis d'invocar-los, ja que com en les imatges marianes, proclamaven en la llengua del país els continguts narratius i conceptuals que, es pretenia, foren alliçonadors, alhora que incloïen les súpliques i les demandes dels fidels. Les vides dels sants -ara seleccionant-ne els fets més humans i afectius-, a més de models catequètics, es transformaren, gràcies a la poesia i la música, en pregària en elles mateixes. Sants medievals, com ara sant Roc o sant Antoni Abat, foren mereixedors de goigs. ${ }^{15}$ Però sobretot se'n compongueren, bé en valencià, bé en castellà, als naturals del regne que foren progressivament canonitzats o, si més no, beatificats -sant Tomàs de Villanueva, sant Lluís Bertran, el beat Gaspar Bono-, i aquells que, com sant Bernat d'Alzira -musulmà convertit al cristianisme i martiritzat per mantenir-s'hi fidel- ${ }^{16}$ i sant Feliu de Girona -fundador de la primera basílica visigoda de Xàtiva- ${ }^{17}$ connectaven -com algunes marededéus trobades, com ara la del Puig i la d'Aigües Vives adés referides- la religiositat contrareformista amb moments fins i tot anteriors a la dominació sarraïna, en una mena d'exaltació dels herois del cristianisme nacional, «(...) fundando [València] toda su abundancia i riqueza en la intercesión de tantos i tan grandes santos como goza (...)» (Martínez de la Vega 1602: 128).

Al llarg del segle XVIII la composició, estampació i difusió de goigs foren fins i tot desmesurades. Com hem plantejat en altres ocasions (Gomis Corell 2013: 258-271), la causa fou la defensa de la

composts en la primera mitat del segle Xvi (Trellat sumàriament fet... 1546: 58-61). Genovés i Olmos (1911: I, 100) refereix una edició anterior del Trellat..., del 1537; posteriorment la cita i transcriu Ribelles Comín (1929/1969: II, 5364), però no conté aquestes llaors. Potser es compondrien en l'interval dels nou anys que separen ambdues edicions.

15 «Llaors del beneyt sent Roch, advocat contra la pestilència», en La vida del glorioso san Roche, abogado de la pestilència, València, 1589, pp. 8-10; aquesta obra degué publicar-se amb motiu de la canonització del sant el 1584; n’hi hagué una altra edició el 1597 (Genovés y Olmos 1911: I, 155; Ribelles Comín 1969 [1929]: II, 41). El 1659 es publicaren en full solt a Barcelona: Goigs en alabança del gloriós sant Roch, advocat contra la pestilència, Barcelona, Martí Jalabert, 1659; Batlle (1924: 55); del segle XVIII són els Goigs en alabansa del gloriós sant Roch, advocat contra la pestilència, de la confraria de la Plaça Nova, Barcelona, Mariano Soldevilla, s. a. [ca. 1743] (Batlle 1925: 96), els quals, partint dels anteriors, introdueixen variants i cobles noves. Els goigs de sant Antoni Abat de Betxí els compongué el 1650 Pere Miquel Bernat, rector de la parròquia d'aquella localitat, a partir de Los goigs del benaventurat sant Antoni, abat, text català estampat en full solt de principi d'aquella centúria (Batlle 1924: 15), del qual prenen introducció, respòs i diverses cobles; el text està manuscrit al Llibre de comptes de la ermita del gloriós sent Antoni de la present vila de Bechí, custodiat a l'arxiu d'aquesta parròquia. Han estat transcrits per Antoni Meneu i Gaya (1995: 2), text que reprodueix Breva i Franch (2013: 126-128).

16 Gozos en lengua lemosina que de tiempo inmemorial se cantan en la capilla de san Bernardo, mártir, de Alzira, en Jaime Cervera [1707: s. n.]; Goigs del gloriós sanct Bernat, màrtir de la villa de Alzirira, s. ll., s. i., s. a [València, anys centrals del segle XVIII], Universitat de València, BH Ms. 870 (060).

17 Goigs al gloriós màrtyr sent Feliu, patró de la il lustre y antiga ciutat de Xàtiva, per a sos devots, València, Josep Garcia, s. a. [entre 1727-1762]; Goigs al gloriós sent Feliu, prebere y màrtir, patró principal de la antiga Xàtiva (ara Sent Felip) [...], s. 11., s. i., s. a. [València, ca. 1760-1780]. Tot i que les estampacions que en coneixem són del segle XVIII, Ribelles Comín (1939: III, 25-26) els data de final del segle XVI. 
Joan Carles Gomis Corell. Històries escrites, històries cantades i històries pintades. Els goigs en el Barroc valencià

manera barroca d'entendre la religió, sentimental i ampul losa, enfront d'una altra més intel lectiva i austera propiciada per la progressiva introducció i assentament de les noves idees il lustrades i, en certa mesura, també de les jansenistes. Per a contrarestar-ne la propagació, l'Església fundà escoles i seminaris i propicià les festes i la literatura devocional. En una conjuntura com aquesta, els goigs -ara tots composts en castellà, però- foren instrument propagandístic fonamental, acrescuts més encara en el si d'un moviment tradicionalista que, oposat a les idees universalistes de la Il lustració, promulgava el conreu literari dels gèneres tradicionals.

\section{Goigs i música}

Els goigs es cantaren des de llurs inicis: «(...) cantaré ab gran amor /vostres goigs, Senyora mya (...)», escrivia Joan de Campos; «Vostres goig ab gran plaer / cantarem, Senyora mia (...)», comencen dient Los goigs de la Verge Maria del Roser (Trellat... 1546: CIIIIv.). Títols com ara Los goigs de la gloriosa Mare de Deu de la Concepció, los quals se cantan en la Encarnació, ${ }^{18}$ o Cançó de la beneita Verge Maria, Mare de Déu, a cantar al so "Si bé em sóc malmaridada, jo me n’he..." (Fuster 1827: I, 293; Villanueva 1902: II, 197-198) no en deixen cap dubte; el segon fins i tot indica que en alguns casos s'empraren melodies manllevades d'unes altres cançons, pràctica que continua essent habitual en la tradició oral. Però no sempre degué haver estat així, ja que alguns es cantaven en convents, monestirs i grans parròquies on hi havia capella musical. Ara bé, n’han pervingut molt pocs testimonis amb notació musical, la qual cosa dificulta la reconstrucció sonora d'aquells cants.

La Ballada dels gotxs de Nostra Dona, en vulgar cathallan del Llibre Vermell és, com tantes vegades s'ha dit, la primera composició en català dedicada als set goigs marians de la qual s'ha conservat la notació. Música monòdica, sens dubte com amb la que el notari Joan de Campos cantava «ab gran plaer» els goigs del seu notal, o fra Gaspar Bono, en la solitud de la seua cel la, cantava goigs a diversos sants, especialment «(...) a su milagroso paysano san Vicente Ferrer, cuyos loores, que comúnmente llamamos gozos, le servían de mucho recreo, y les cantava muy de ordinario» (Ortí y Mayor 1750: 152; vid. supra nota 14). De final del segle XVI i principi del XVII n'hi ha alguns de polifònics: el Madrigal I. Goigs de Nostra Dona, de Joan Brudieu, del 1585 (Casas 2005), ${ }^{19}$ i un poc

18 [Vilaespinosa, P.], Los goigs de la gloriosa Mare de Deu de la Concepció, los quals se cantan en la Encarnació, s. 1l., s. i., s. a. [València, 1501?], Universitat de València, BH CF/4 (16); Genovés y Olmos (1911: I, 93-94), a més d'aquesta edició, en cita una altra que detalla la data, 1525, i l'autoria de Pere Vilaspinosa.

19 El text poètic d'aquests goigs és el mateix que, amb lleugeres variants, copià J. P. Fuster (1827: I, 284, 292-293) del còdex del convent dominicà de Sant Onofre -que es conservava a la biblioteca dels ducs de Sogorb i es perdé quan la guerra del francès-, on també es contenia la susdita Cançó de la beneyta Verge Maria.... Ambdues composicions es consideren dels goigs valencians més primerencs, ja que Fuster diu que el còdex «parece ser del último del siglo XIII o del principio del XIV (...)». Joan Baptista Batlle (1924: 14) reprodueix un full del segle XVII de Los set goigs de la Verge Maria de Pietat, de la col lecció de Salvador Barbra, amb un text bastant semblant, tot i que no n’indica procedència, impremta ni datació precisa; també el reprodueix De Courcelles (2008: 392, il lustració XIV). És el text dels anomenats Goigs dels ous, que es canten Dissabte Sant al Conflent i parts del Rosselló (Puiggari 1897: 6-8, [14]; Association Départamentale... 1996: 95-98). 
Joan Carles Gomis Corell. Històries escrites, històries cantades i històries pintades. Els goigs en el Barroc valencià

més tardans, d'entre el 1608 i el 1610, els que Joan Baptista Comes compongué dedicats a les quatre invocacions de la Capella Major del Col legi de Corpus Christi de la ciutat de València (Báguena Soler 1955; Gomis Corell 1999a: 187-195). De 1702 és la publicació dels goigs de sant Bru, amb música polifònica de Jerónimo de la Torre. ${ }^{20}$

Polifònic degué ésser en el Barroc el cant dels goigs, si més no, en aquelles institucions amb capella musical. Jaume Rebullosa, prior del convent de Sant Doménec de Balaguer, dóna valuoses informacions al respecte en el llibre de festes de la canonització de sant Ramon de Penyafort celebrades a Barcelona el 1601. Hi constata, primer de tot, la particularitat d'unes «(...) canciones en lengua catalana que acá llaman gozos, en alabança del mismo santo». Els cantaven després de vespres els religiosos del convent de Santa Caterina -on se'n venerava la relíquia- a «canto de órgano», «con mucha música», juntament amb «(...) muchos motetes y canciones en su loor» (Rebullosa 1601: 21, 22, 36). També Joan Esteve Mir, cronista de la ciutat de Barcelona, escriu al Manual de Novells Ardits que, efectivament, en la visita del consellers a Santa Caterina «los frares del monestir han cantat uns goigs del dit gloriós sant (...)» (Cardona i Roig 1990: 33). Altres vegades es cantaven, igualment a cant d'orgue, a «petición» dels qui acudien al convent per adorar el sant (Rebullosa 1601: 39, 40, 55, 58, 89). No especifica Rebullosa a qui se'n feia la petició, però essent una composició polifònica i havent dit que els cantaven els religiosos del convent, degué fer-se a la capella musical, els membres de la qual eren els únics amb les destreses necessàries per a interpretar polifonia. ${ }^{21}$ Només quan hi acudiren xiquets i donzelles, cantaren ells mateixos els goigs, tal vegada amb una melodia monòdica, tradicional, perquè en aquests casos no s'hi diu que foren a cant d'orgue (Rebullosa 1601: 79, 95, 105, 115, 122, 163, 225, 243, 249, 251, 254, 282, 303 [per: 290], 297, 339, 447, 449-450). No transcriu Rebullosa aquests goigs, però degueren ésser els Goigs $i$ alabanses del gloriós sant Ramon de Peñafort, cathalà, del orde de predicadors, composts per un religiós cathalà de dit orde, i també els Llahors del gloriós pare sant Ramon de Penyafort, ambdues composicions publicades, entre altres poesies, en plecs solts amb motiu d'aquelles festes. ${ }^{22}$

20 Gozos de las virtudes y milagros del seráphico y gran patriarcha san Bruno, fundador de la Sagrada Orden de la Cartuxa. Tono nuevo y proprio a los sobredichos gozos compuesto por el maestro Gerónimo de la Torre; Fran. Gazán esculpit. Barcelona: [s.n.], 1702, Biblioteca de Catalunya, TOP: I Go A R.15134; vid. Ballús i Casòliva, Ezquerdo Estevan (2013: 83-111).

21 Pocs anys després de Rebullosa, García de Caralps (1617: 96v.-97r.) descriu que els cecs tenien per habitud cantar, a més draltres oracions, els goigs dels sants, i a ells n’encomanaven els devots el cant:

\footnotetext{
Acostumbran los ciegos en esta ciudad de Barcelona cantar y rezar las oraciones y coplas de los santos, y estar delante de sus capillas los días de sus fiestas; y entre otras oraciones que cantan y rezan es la oración de san Oleguer. (...) Cada día se hallan delante de la capilla de san Oleguer ciegos que viven de rezar la oración o coplas de san Oleguer a instancia de los devotos, que les dan un dinero por cada vez.
}

22 Goigs y alabanses del gloriós sant Ramon de Peñafort, cathalà, del orde de Predicadors, composts per un religiós cathalà de dit orde, Barcelona, Jaume Cendrat, 1601; Llahors dels gloriós pare sant Ramon de Penyafort, Barcelona, Sebastià de Cormellas, 1601; Los goigs dels gloriós pare sant Ramon de Penyafort, Barcelona, Joan Amelló, 1601; reproduits per Batlle (1924: 22, 23, 24); cf. Benach i Torrents (1961/2005), Cardona i Roig (1990: 61-89), Ettinghausen (1999: 490-502). 
Joan Carles Gomis Corell. Històries escrites, històries cantades i històries pintades. Els goigs en el Barroc valencià

També a València existia la pràctica de demanar que es cantaren goigs. En la Vida, virtudes, milagros y festivos cultos de santo Thomás de Villanueva... relata Ortí y Mayor (1731: 286, 301) que el sastre Juan Ten, en comprovar que no «(...) quedava la menor duda en la muerte de su hijo [Baltasar, de tres anys], se encaminó a la iglesia de el Socorro y, postrado delante de la sepultura de nuestro santo, dispuso le cantassen unos gozos y le rogó alcanzasse para su hijo la vida (...)». El març de 1602, Isabel Periz, esposa de Juan Periz, llaurador, després d'un part complicat i perillós, en agraïment a l'aleshores encara beat, anà a escoltar missa «(...) al convento de el Socorro, y dexó limosna para este sacrificio y para unos gozos». Ara bé, a diferència de Rebullosa, Ortí y Mayor no dona cap indicació de com sonaven aquells goigs. ${ }^{23}$

Un any després de Barcelona, també la ciutat de València celebrà festes en honor del nou «(...) santo catalán Raymundo, las hizo tan grandiosas en su canonización el año 1602 con no aver nacido ni vivido en ella, si solo por ser de la corona» (Martínez de la Vega 1620: 10). El llibre d'aquelles festes, escrit pel dominicà Vicente Gómez, és prolix en descripcions: lluminàries, focs artificials, vols de campanes, processons, imatges. Diversitat de música i d’instruments -«(...) tañían los órganos, que ay tres en este convento (...) Luego los menestriles, interpolando clarines, trompetas, atabales y vigüelas de arco.»-; exaltació de «(...) la capilla de la Iglesia Mayor, que es de las famosas y regalada que hay en Iglesia de la christiandad, sin agravio de las más principales»; cant d'antífones i d’un «(...) regalado villancico con ricas bozes $(. .)$.$» ; també de la Salve amb «(...) menestriles y cornetas y un juego de$ flautas (...)»; després de la processó «(...) dixeron los cantores de la Santa Iglesia [catedral] un motete y los infantillos un verso (...) y mil diversidades de música (...)»; inclús curiositats interpretatives com ara unes letrillas, interpolades entre el salm Laudate Dominum in sanctis eius, acompanyades d'orgue i rabel (Gómez 1602: 12, 13, 23, 24, 61-64, 160). Sonets, romanços, redondillas, estanças, sentències i diverses altres poesies, totes en castellà, es presentaren al certamen literari. «La música fue mucha y muy buena (...)» (Gómez, 1602: 493), però no es fa cap referència al cant de goigs.

23 No es coneix certesa documental de quins foren aquells goigs. Per la data d'aquest darrer miracle, que Ortí y Mayor diu extraure del procés de canonització de l'arquebisbe, no pogueren haver sigut, si n'atenem al títol, els Goigs del gloriós sant Thomàs de Vilanova, arquebisbe de València, s. 11., s. i. s. a. [València, ca. 1740-1760], ja que el refereixen com a sant, i la canonització en fou el 1659. Almarche (1917: 172-173) els data, efectivament, en aquell moment, però la crònica de la festa que celebrà la ciutat de València per aquella canonització (Ortí 1659) no diu res referent a la composició ni al cant de goigs. Hagueren de tindre diverses estampacions, per tal com la transcripció que en fa Almarche a partir d'un «(...) manuscrit que conserven les monges del convent de la Santíssima Trinitat de València, tret per lo reverend Pere Sucias», té, respecte del full de mitjan segle XVIII, lleugeres variants del text i una cobla distinta. Si Ortí y Mayor portà al seu propi temps el passatge del cant dels goigs, potser es referiria als específics del convent dels Socors, en castellà, que hagueren de compondre's en paral lel a l'hagiografia del sant arquebisbe: Gozos del glorioso santo Tomás de Villanueva, arzobispo de Valencia, venerado en el Real Convento de Nuestra Señora del Socorro, extramuros de la misma ciudad, s. ll., s. i., s. a. [València, ca. 1750-1770], Universitat de València, BH CGS/303; Gozos del glorioso santo Tomas de Villanueva, arzobispo de Valencia, venerado en el Real Convento de Nuestra Señora del Socorro, extramuros de Valencia, donde descansa su santo cuerpo, s. 1l., s. i, s. a. [València, ca. 1750-1780], Universitat de València, BH Ms. 0870 (100) i (228); Gozos al glorioso santo Tomás de Villanueva, arzobispo de Valencia, venerado en el Real Convento de Nuestra Señora del Socorro, extra muros de Valencia, s. 11. [València], viuda de Agustín Laborda [ca. 1776-1800]. De ca. 1800 hi ha a l'Arxiu Musical de la Catedral de València, núm. 376, una composició musical d'aquests goigs per a quatre veus, dos violins i dues trompes (Climent 1979: I, 85).

SCRIPTA, Revista internacional de literatura i cultura medieval i moderna, núm. 11/juny 2018/pp. 131-158

ISSN: 2340 - 4841 doi:10.7203/SCRIPTA.11.12589 
Joan Carles Gomis Corell. Històries escrites, històries cantades i històries pintades. Els goigs en el Barroc valencià

Igual ocorre en els llibres de festes de la beatificació de l'arquebisbe Tomàs de Villanueva (Martínez de la Vega 1620) i de la seua canonització (Ortí 1659); i també en el de les festes de la proclamació del privilegi marià de la Puríssima Concepció (Valda 1663). Misses, sermons, altars, carros triomfals, lluminàries, nanos i gegants, jeroglífics, certàmens literaris i copiosa poesia -villancicos, seguidillas, coplas, quintillas i letras- pràcticament tota en castellà, i molta música. Tanta, que per a les festes de beatificació de l'arquebisbe Tomàs de Villanueva, a més dels ministrers i instrumentistes «(...) que hay en esta ciudad [de València] muchos, por ser grande i populosa (...) baxaron para este caso, sin duda, a la ciudad todos los del reyno» (Martínez de la Vega 1620: 49).

Això no obstant, només en alguns pocs passatges pot implícitament sobreentendre's -amb més bona voluntat que no pas cap altre indici cert- el possible cant de goigs en aquelles festes. Així, el 16 de gener de 1663, l'endemà mateix d'haver-se rebut en la ciutat de València el Breu pontifici de la declaració de la Puríssima Concepció, s'organitzà espontàniament una processó en la qual els estudiants de la universitat «(...) alternando con la música y vítores, cantavan devotamente sus himnos» (Valda 1663: 34). Potser entre aquests himnes estigueren els anteriorment esmentats Goigs de la Concepció. També potser es cantaren quan, pocs dies després, en la capella del Reial se celebraren els oficis i «(...) la música de la Santa Iglesia [catedral] con primorosos quiebros, con dulzes sustenidos y con afecto propio, cantó los divinos elogios [de la Puríssima Concepció]»; ${ }^{24} \mathrm{O}$ en la processó general, en el darrer carro de la qual anava «(...) acorde música que en dulcíssimas consonancias cantava a la Virgen ayrosos tonos» (Valda 1663: 176, 285), i «tono nuevo» s'anomena en l'estampació adés referida dels Gozos de las virtudes y milagros del seráphico y gran patriarcha san Bruno la composició polifònica de Jerónimo de la Torre per cantar-los (vid. nota 20).

Encara que aquests llibres no esmenten explícitament el cant de goigs, és segur que a València se'n cantaven. Ho constaten, primer de tot, les constitucions sinodals del 1594 de l'arquebisbe Joan de Ribera (1594: [1-2]):

\footnotetext{
(...) el sínode considera que les imatges de les confraries (...) a les quals més afecte té el poble, en la nostra ciutat es tenen, això no obstant, amb menys decor que en unes altres, per tal com es col loquen en les cases dels menestrals, en llurs tallers, sabateries (...). Algunes vegades fins $\mathrm{i}$ tot les duen a bodegues i, de manera habitual, a habitacions on de nit es giten a dormir i s'hi fan altres coses semblants (...). Per això, en quedar les esglésies parroquials en una soledat excessiva, dissabtes al vespre s'acudeix de tot el veïnat a aquelles habitacions profanes $i$ allí cantors i citaristes [guitarristes?] canten la Salve regina, goigs i altres pregàries, com als edificis sagrats.
}

En segon lloc, continuaren component-se'n al llarg del segle XVII i, de manera especialment abundosa, si bé en castellà, en el segle XVIII, i una gran part d'aquests són els que en l'actualitat

24 Alguns títols de final del segle XVIII canvien el nom goigs pel d'elogis: Breves elogios al beato Juan de Ribera, patriarca de Antioquía, arzobispo, virey y capitán general de Valencia, que se cantan el día de su fiesta en el Real Colegio de Corpus Christi, s. 11., s. i., s. a. [València, ca. 1800], Universitat de València, BH Var. 010 (036) i (037). 
hi segueixen vigents. En altres casos ho indica el títol, com en els ja esmentats Gozos en lengua lemosina que de tiempo inmemorial se cantan en la capilla de san Bernardo, mártir, de Alzira (Cervera 1707: s. n.), els quals, paradoxalment, ja no es canten. També perquè alguns dels més específics del segle XVII, com ara els de la Mare de Déu del Puig -Almarche (1917:120) en diu que «(...) se canten actualment en música pròpia y antiga en lo monastir del Puig»- i els de la Mare de Déu d'Aigües Vives -n'hi ha constància, ja s'ha dit, que el 1666 ja es cantaven al convent agostí on estava la imatge (vid. nota 9)-, i també els de la Mare de Déu del Roser, de final del segle XV o principi del XVI, ${ }^{25}$ continuen cantant-se actualment amb melodies exclusives que mai no es manlleven, clarament anteriors a la música tonal, les quals, a més, tenen semblances estructurals amb els goigs polifònics de Joan Baptista Comes (Gomis Corell 1999b: 171-195). ${ }^{26}$

Els goigs polifònics de Comes no pogueren ésser un cas aillat en el corpus musical valencià de principi del segle XVII. Resulta difícil concebre'ls obres úniques sense relació amb la pràctica musical del moment. Algun antecedent més o menys directe hagueren de tindre; també algun conseqüent més enllà d'uns altres tres goigs que n’assimilaren, tot i que sense polifonia -si més no, no en coneixem constància escrita- els trets estructurals, fins que més d'un segle després Jaime Pradas componguera, sobre text en castellà, goigs a sant Miquel, la Mare de Déu del Carme i sant Joan Nepomucè (Climent 1979: 373, 388). També a València, els goigs, almenys els que es cantaven en parròquies importants, convents $\mathrm{i}$ monestirs on hi havia com a mínim una reduïda capella musical $i$ un o, fins i tot, diversos orgues, s'interpretaren amb polifonia.

Ara bé, que no se n'haja conservat la pauta indica que degué ésser polifonia improvisada, és a dir, contrapunt -«contrapunto suelto» l'anomena Tosca al Compendio mathemático (1727 [1709]: II, 474). Durant les festes de beatificació de l'arquebisbe Tomàs de Villanueva, la seua imatge fou rebuda en la catedral amb «(...) salva de ministriles, cornetas, órgano i varillas de cantores (...)» (Martínez de

25 Els Goigs de la Verge Maria del Roser han estat considerats tradicionalment obra de sant Vicent Ferrer. El qui primer recollí aquesta atribució potser fou Francisco Vidal y Micó (1735: 27), frare del convent de Predicadors de la ciutat de València, el qui recolzant-se en la «constante y segura tradición» deixà escrit que:

\footnotetext{
(...) san Vicente es el autor de saludar con el Ave María a la Virgen Madre antes del sermón (...) y así propio que es autor de los Gozos a la Virgen del Rosario que se cantan en valenciano (...) aunque de esto [de la devoció al Rosari] no hagan mención los escritores de su vida, ni se lea cosa alguna en sus sermones, por ser otro su principal assumpto, aviéndole Christo escogido por apóstol y predicador del Juizio, y estar amortiguada en aquellos tiempos esta devoción ( $\mathrm{y}$ aun el nombre de Rosario, porque se llamaba Psalterio) (...)
}

No res en diuen els bibliòfils valencians d'aquella divuitena centúria, circumstància significativa perquè Vicente Ximeno (1747: I, 24-32) cita Francisco Vidal a l'hora de constatar algunes edicions de les obres del sant (cf. Rodríguez 1747: 14-21). Sí que en fa esment, seguint Francisco Vidal, Justo Pastor Fuster (1827: I, 18). També s'estampà així en alguns fulls de goigs del segle XVIII: Goigs de la Verge Maria del Roser, composts per lo pare san Vicent Ferrer, s. ll., s. i., s. a. [València, Agustín Laborda, ca. 1760-1776], Universitat de València, BH Ms. 0870 (147). Recentment han estat atribuïts a Bernat Fenollar (De Courcelles 2017: 275).

26 Només dos goigs, que hom haja pogut constatar, manlleven la melodia pròpia dels de la Verge Maria del Roser: els Gozos a la Divina Pastoria de Banyeres i els Gozos a santa Bárbara de Benitatxell (Seguí 1973: 28). 
la Vega 1620: 155). No vol dir açò que en aquell precís moment s'entonaren goigs, però hi queda constatada la pràctica de les varillas o varetas -varetes, hagueren de dir en valencià, suposem-, que consistien, en general, en «(...) hazer contrapunto de repente (Cerone 1613: 608) o, com dirà posteriorment Nassare (1723: 161), «(...) echar el contrapunto de repente». ${ }^{27}$ Els cantors, sobre melodies ja fetes, bé de cant pla, bé de cant d'orgue, construien «diferencias de contrapunto» (Tosca 1727 [1709]: II, 474), ${ }^{28}$ ampliant i modificant les composicions fins a l'extrem que, quan les festes de la canonització de sant Tomàs de Villanueva, Ortí (1659: 252) s'admirà de la música que s’hi interpretà perquè:

(...) fue tan deleytosa y agradable como se puede inferir de la dirección y destreza del maestro de capilla, con que sin embargo de haverla continuado todos los días, cada vez suspendía tanto como si saliera de nuevo, de más de que siempre se le ivan añadiendo varias circunstancias que la realçavan, de suerte que siempre se experimentavan muchas novedades $(\ldots)$

Determinar quins tipus de contrapunt s'usarien per a cantar goigs potser seria massa agosarat. Això no obstant, amb moltes reserves, podria aventurar-se'n una hipòtesi. Tenint presents les característiques de les composicions de goigs que a hores d'ara coneixem -Brudieu, Comes, de la Torre- i considerant l'afirmació de Cerone (1613: 565-594) que en les capelles musicals el contrapunt comú era el més usat, els goigs hagueren de cantar-se habitualment a contrapunt pla i disminuit a dues veus, a contrapunt a una veu sobre cant d'orgue o a contrapunt senzill a tres veus sense imitacions. Com que el cant d'orgue s'escrivia, les possibilitats es reduirien a dues. Sens dubte recialla i ensems testimoni d'aquella pràctica contrapuntística improvisada, han perdurat en la tradició oral, podria dir-se que fossilitzats per les successives simplificacions per adequar-los a les possibilitats d'intèrprets sense instrucció musical, uns pocs tipus melòdics polifònics molt senzills -només a dues veus- per a cantar goigs. Alguns es limiten a fer una veu paral lela a distància de tercera, bé superior, bé inferior, sobre la melodia, però uns altres condueixen en algun moment l'altra veu per moviment oblic i fins i tot contrari. ${ }^{29}$

27 Dionisio Preciado (1979: 345-347) afirma que las varillas o varetas només se feien sobre el cant pla, afegint-li intervals a distància de les consonàncies perfectes, com si es tractara d'un organum paral lel; Fernández de la Cuesta (2002: 561) sembla associar-les a les glosses gregorianes; sobre el contrapunt improvisat en la pràctica polifònica hispànica vid. Fiorentino (2014: 148-160).

28 Recull de Cobarruvias (1611: 61v., sub vocem vaca) l'expresió diferències de contrapunt en definir l'accepció de vaca com a «(...) una cierta sonada entre músicos, y sobre ella han hecho grandes diferencias de contrapunto y pasos forçados; y díxose assí por empeçar el villancico con estas palabras: "Gárdame las vacas, carillejo, por tu fe", etc.».

29 Sense ser-ne un inventari complet, per a aquests tipus melòdics polifònics en la música tradicional valenciana vid. Seguí (1973: 31-34, 37, 39-43; 1980: 848, 852, 857, 859, 861, 864, 866-867, 869, 870-871,876-878; 1990: 464, 465, 473, $475,480,485,486-487,488,489,494,495,496,500,501,504-505,507-511)$; per una anàlisi musical detallada sobre algun en particular vid. Gomis Corell (1993: 41-45, 49-52; 1996: 485-486, 495). 
Joan Carles Gomis Corell. Històries escrites, històries cantades i històries pintades. Els goigs en el Barroc valencià

Els goigs necessàriament són cant. No cal exposar ara i ací la importància que el cristianisme ha atorgat sempre a la música en la litúrgia i la pregària per a demostrar que la música és element consubstancial als goigs. Foren, primer de tot, composicions de lloança mariana i, posteriorment, per extensió, d'altres personatges celestials. Eren himnes i, com a tals, necessitaven obligatòriament la música per a complir tots els requisits establerts per sant Agostí: «cant, lloança i lloança de Déu» (Enarrationes in psalmos, 148, 17). Ara bé, en el Barroc, aquella música no fou tan sols lloança, sinó principalment «(...) solenidad sonora (...) preciso festejo para celebridad (...) devota i divina elevación de los ánimos», com digué Joan Baptista de Valda (1667: 233) de la música que sonà en les festes de la Puríssima. És a dir, exaltació emotiva que volia convèncer seduint els sentits i excitant els afectes. Essent així, la música feia més grata i convincent la narratio de les històries contades pels goigs i, com que la forma de la dansa trobadoresca els feia cant responsorial, permetia memoritzar la invocatio i repetir-la cada vegada després de cada cobla.

A fra Gaspar Bono, quan cantava goigs, especialment els de sant Vicent Ferrer, «(...) le servían de mucho recreo (...)» (Ortí y Mayor 1750: 152). Fra Pere Esteve «(...) cantava y hazía cantar [goigs] a la imagen de Nuestra Señora de la Montaña de Santidad a todos los que llegavan al siervo de Dios con particulares necesidades, y se experimentaron varios sucessos de consuelo (...)» (Mercader 1677: 100-101). El cant dels goigs, la música en general, afegia un valor essencial a aquells moments d'oració: confortava i assossegava l'ànima. Aquesta, en escoltar música, recobrava la «(...) memoria perdida, /de su origen esclarecida / [...elevant-se] a la más alta esfera / [.. on] ningún accidente / estraño y peregrino oye o siente (...)», com diu fra Luis de León. En definitiva: la música, el cant dels goigs, és consolatio.

\section{Goigs i imatge}

El títol amb què el 1710 Josep Llopis, impressor de Barcelona, estampava uns nous goigs de la Verge de la Gleva, Cobles que ab segur afecte, no menos que ab devoció deguda, los devots de la Verge de la Gleva, a sos peus, cantan (Batlle 1925: 37), compendia ben explícitament tots els requisits que han de complir aquestes composicions: text -és a dir, l'oració-, cant, cant devot i convençut, i cant «a sos peus», és a dir, davant la imatge i reverents - «als que os criden humillats» és la condició, recorde’s, que seguint els dictats de Trento, imposen els Goigs de la Mare de Déu dels Desamparats per obtenir-ne l'empara. Els goigs, tant que instrument de culte, sempre s'han cantat davant la imatge sagrada o relíquia a la qual estan dedicats i, per tant, al mateix lloc de veneració -Cobles en alabansa de Nostra Senyora de Grasolet, las quals se cantan devant de la sua santa imatge, en sa pròpia capella, no hi ha dubte-,${ }^{30} \mathrm{si}$ més no a partir dels postulats contrareformistes, els quals incidiren especialment-davant la negació dels reformadors- en la necessitat d'invocar els sants, les relíquies i les imatges i de visitar-ne amb

30 Cobles en alabansa de Nostra Senyora de Grasolet, las quals se cantan devant de la sua santa imatge, en sa pròpia capella, Girona, Jeroni Palol, 1670; reproduït per Batlle (1924: 64). 
Joan Carles Gomis Corell. Històries escrites, històries cantades i històries pintades. Els goigs en el Barroc valencià

freqüència els llocs de veneració per atènyer el beneficis de Déu. Manava, a més, que les imatges estigueren als temples, i que allí se'ls retés el corresponent honor i veneració (López de Ayala 1787: 355-358). En aquest aspecte, l'arquebisbe Joan de Ribera (1594: 3) fou especialment gelós:

\begin{abstract}
(...) ordenem, sots pena d'excomunicació automàtica (...) que els titulars de les confraries tornen les imatges, una rere l'altra, als llocs sagrats que els confrares, per pròpia decisió, determinen; i que, per a preservar-les, no tornen a les cases dels laics. (...) ordenem, sots la mateixa pena, que aquells confrares que retenen les esmentades imatges en llurs cases, que en els tres dies posterior a la promulgació d'aquest decret, les tornen als llocs sagrats. A més, ordenem i exhortem amorosament a totes les confraries que, a partir d'ara, no donen a les dites imatges menys honor a les esglésies que abans en llurs cases, sinó igual o fins i tot major.
\end{abstract}

Essent així, per a tindre la imatge sempre present i poder cantar-li goigs en qualsevol moment, les estampacions, a més d'especificar-ne al títol el lloc concret de veneració amb detalls ben precisos $-\mathrm{a}$ «(...) una llegua de la ciutat de Dènia, junt a la montanya de Mongó» $-^{31}$ n’incorporaren ineludiblement la reproducció:

Como está tan entrañada en los corazones de los fieles la devoción del santo Christo [de Sumacàrcer], procuran muchos lograr la estampa y gozos de este divino Señor; porque, ya que no les es possible lograr siempre su deseada presencia, para acallar su devoción ingenian, como verdaderos amantes, entretenerse con el retrato en ausencias de su original (Selva 1740: 171).

El full de goigs era, realment, estampa devocional que, a l'àmbit i a l'espai personal i domèstic substituia aquelles imatges que necessàriament havien de venerar-se -així ho havia determinat el Concili de Trento- als llocs sagrats. «En las paredes no avía guadamasiles, lienzos ni otras pinturas que estampicas de papel muy ordinarias de Nuestra Señora, de san Joseph, de santa Ana, de san Vicente Ferrer con los gozos al santo en lengua valenciana (...)» diu Ortí y Mayor (1750: 90) en descriure la cel la de fra Gaspar Bono. Les imatges de les estampes incitaven la pietat i el fervor, alhora que exercien especials poders de protecció, els quals, ben especificats, també formaven en alguns casos part del títol dels goigs: «(...) abogado contra las fiebres malignas y cánceres», «(...) especialíssimo abogado de los que padecen mal de piedra, ijada y orina $(\ldots.) .^{32}$ A més, «(...) si están tocadas a la misma imagen [original] (...) se pueden asimismo estimar por reliquias, o tenerlas en

31 Goigs de la sagrada imatge de Jesús Pobre, venerada en lo hospici que li fundà el venerable pare fra Pere Esteve, una llegua de la ciutat de Dènia, junt a la montanya de Mongó, Valencia, Francisco Burguete, s. a. [entre 1755 i 1768]; Goigs de la sagrada imatge de Jesús Pobre, venerada en lo hospici que li fundà el venerable pare fra Pere Esteve, una llegua de la ciutat de Dènia, junt a la montanya de Mongó, s. ll., s. i., s. a. [València, ca. 1760-1780], Biblioteca Nacional de España, VE/1444/466; cf. Mercader (1677: 121-123).

32 Gozos del beato Nicolás de Logobardis, religioso oblato del orden de Minimos de san Francisco de Paula, abogado contra las fiebres malignas y cánceres, s. 1l., s. i., s. a. [València, ca. 1760-1780], Universitat de València, BH Ms. 0870 (015); Gozos de san Liborio obispo, especialíssimo abogado de los que padecen mal de piedra, ijada, y orina, venerado en el Real Convento de la Merced de Valencia, s. 11., s. i., s. a. [València, ca. 1760-1770], Universitat de València, BH Ms. 0870 (093). 
Joan Carles Gomis Corell. Històries escrites, històries cantades i històries pintades. Els goigs en el Barroc valencià

tal veneración (...)» (Ares 1640: 212v.). Els fulls de goigs assolien així eficàcia per ells mateixos: els goigs invocaven i, a la vegada, a través de llur materialització impresa, s'invocava. Quasi talismans protectors front a necessitats i desgràcies tant materials com espirituals, sobretot a les zones rurals. ${ }^{33}$

Proliferaren, per tant, abundosament les estampes, moltes vegades amb una finalitat taumatúrgica. En 1602, quan beatificaren l'arquebisbe Tomàs de Villanueva (Martínez de la Vega 1602: 24), d'estampes del nou beat,

\begin{abstract}
(...) uvo sin número, pues sólo los religiosos trajeron de Roma más de tres mil de folio grande, finísimas, con sus milagros en contorno de ellas por orla; sin otras muchas que mercaderes particulares avían echo traer a su cuenta, i infinitas de diferentes suertes que en la ciudad se avían cortado en madera i láminas de cobre, de que uvo tan notable expedición que admira.
\end{abstract}

Aquest valor d'estampa obligava que les imatges dels fulls foren reproduccions més o menys fidels -segons també el bon fer del gravador i les tècniques a disposició- de les originals. En qualsevol cas, sempre recognoscibles pels fidels, perquè era la imatge, situada en la part superior, centrada, ben visible, i no pas el text, la que identificava l'oració i el destinatari. Calia una concordança inequívoca entre la imatge gravada, l'original i el títol dels goigs que, amb més o menys indicacions, la identificava, més encara quan es creia que el poder intercessor i benefactor era de la imatge particular, no de la invocació. Així ocorre en la xilografia que encapçala el full dels Goigs a Nostra Senyora d'Aigües Vives respecte de la imatge escultòrica original (Figs. 1 i 2).

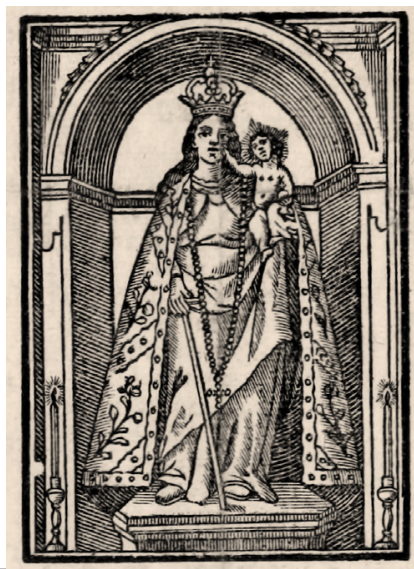

Fig. 1. Autor desconegut (1760 1770 ca.) Mare de Déu d'Aigïes Vives, xilografia, repertori de la impremta Laborda, València

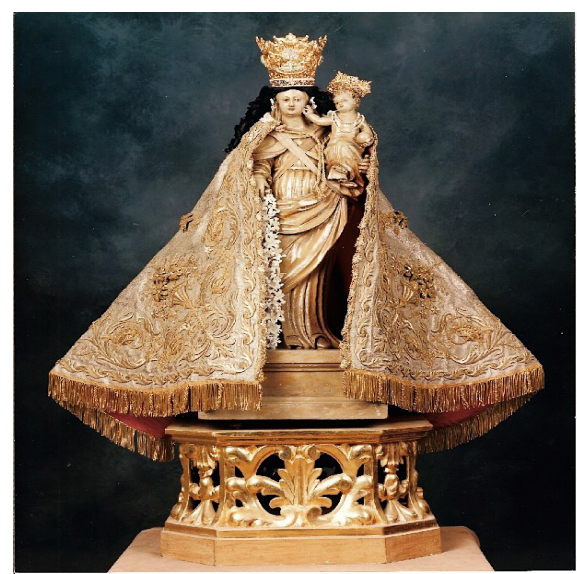

Fig. 2. Robres Miralles, A. (1736) Mare de Déu d'Aigües Vives, estuc de guix i calç, 58 cm., Església Parroquial de l’Assumpció, Carcaixent.

33 Al respecte, vid. Caro Baroja (1985) i Christian (1990). 
Joan Carles Gomis Corell. Històries escrites, històries cantades i històries pintades. Els goigs en el Barroc valencià

En uns altres casos, el gravat reprodueix la imatge original i, davall, representa de manera recognoscible la ciutat o lloc sobre els quals estén la protecció o patronatge, construint una imatge que conceptualment associa invocació i territori, transformant-lo en lloc religiós viscut en la quotidianitat de la fe. És el cas de la xilografia del full dels Goigs de Nostra Senyora del Desamparats, estampats a mitjan segle XVIII, tot i que composts -ja s'ha dit- en la centúria anterior (Fig. 3). ${ }^{34}$

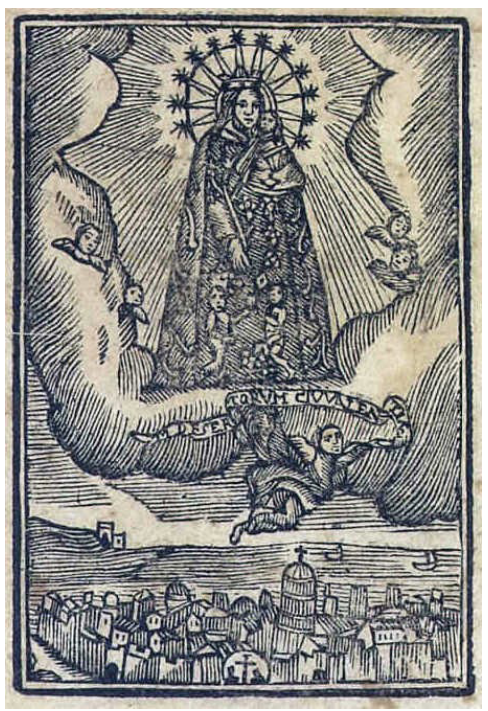

Fig. 3. Autor desconegut (1750 ca.) Nostra Senyora dels Desemparats, xilografia.

Unes altres vegades es representa només el lloc sagrat de veneració, construint una imatge metonímica que, per contigüitat, refereix el lloc i tot el territori sobre el qual la imatge exerceix protecció. És el cas d'una estampació dels goigs de la Mare de Déu del Castell de Cullera, en la qual el gravat en representa la imatge entre una resplendor, voltada de núvols i àngels, i davall el castell en la capella del qual es venera (Figs. 4 i 5 ). ${ }^{35}$

34 Goigs de Nostra Senyora dels Desamparats, s. ll., s. i., s. a. [València, 1750-1760 ca.].

35 [Ríos, José], Gozos a la Virgen del Castillo de la villa de Cullera, s. ll., s. i., s. a. [València, Impremta de Laborda, final del segle XVIII], Universitat de València, BH Ms. 0828 [De Orellana, M. Antonio (recop.)], Gozos de Nuestra Señora con varias invocaciones, f. 269, núm. anterior 139; vid. Gomis Corell (2003a: 67-87). 
Joan Carles Gomis Corell. Històries escrites, històries cantades i històries pintades. Els goigs en el Barroc valencià

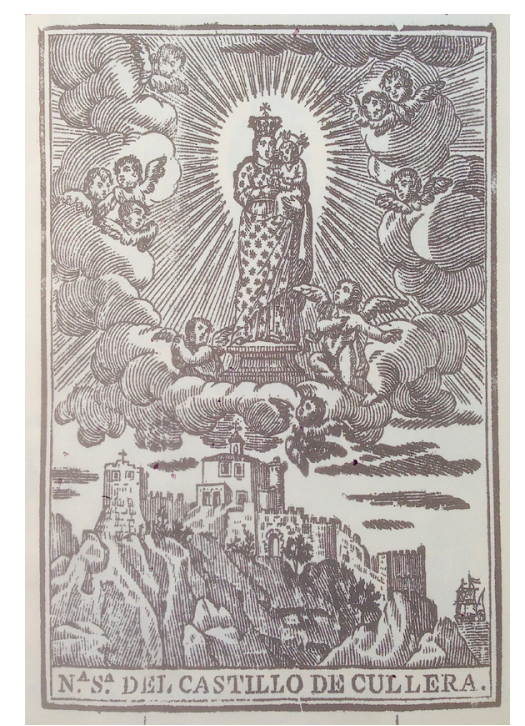

Fig. 4. Autor desconegut (1780-1800 ca.) Nuestra Señora del Castillo de Cullera, xilografia, repertori de la impremta Laborda.

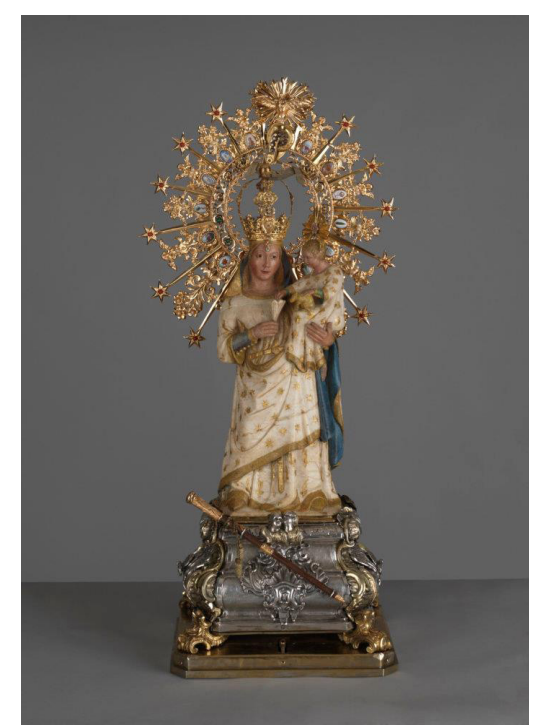

Fig. 5. Autor desconegut (mitjan segle XIV) Mare de Déu del Castell de Cullera, marbre cremabuixcarró, $38 \mathrm{~cm}$., Cullera, capella del castell.

També l'estampació dels Goigs de Nostra Senyora del Puig inclou una xilografia que reprodueix amb fidelitat la imatge rellevada venerada al monestir (Figs. 6 i 7).

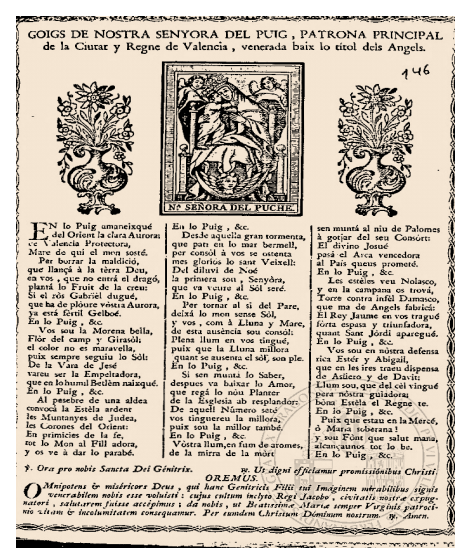

Fig. 6. Autor desconegut (1760 ca.) Nuestra Señora del Puche, xilografia, repertori de la impremta Laborda, València.

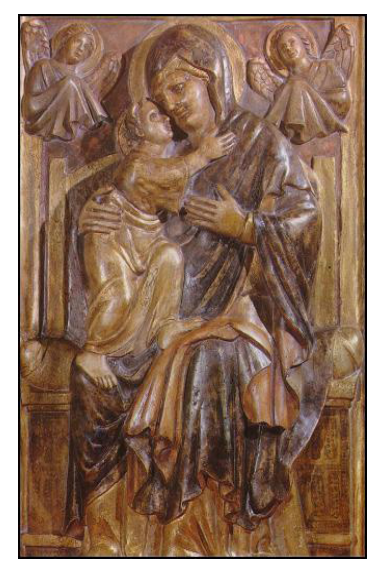

Fig. 7. Autor desconegut (segle VI) Nostra Senyora del Puig, marbre, 98 x $62 \mathrm{~cm}$., Reial Monestir de Santa Maria, el Puig. 
Joan Carles Gomis Corell. Històries escrites, històries cantades i històries pintades. Els goigs en el Barroc valencià

El Concili de Trento també havia atorgat a les imatges una funció didàctica: havien d'instruir els fidels sobre els articles de la fe, mostrar els exemples dels sants i els miracles que Déu havia obrat a través d'ells (López de Ayala 1787: 358). És a dir, havien de transmetre informacions conceptuals i narratives. La imatge reforçava, per redundància, els continguts textuals, els assentava en la memòria, sense renunciar, és clar, a la semblança amb l’original. Garantia, a més, la certesa de la història en fer-la visible. S'hi oferiren dues alternatives: afegir a la representació els elements indispensables que al ludiren i enunciaren els conceptes o esdeveniments narrats al text -és a dir, construir una imatge conceptual-, o construir una escena en la qual diversos personatges situats en un espai més o menys descriptiu realitzaren una acció -imatge narrativa.

L'estampació d'uns nous goigs de la Mare de Déu del Puig en castellà emprà la primera opció, és a dir, la imatge conceptual. ${ }^{36} \mathrm{~A}$ la representació xilogràfica de la imatge devocional real, l'autor afegí els elements necessaris per a reconèixer la troballa portentosa, tantes vegades escrita, de la imatge, argument central de la seua devoció: la campana que l'ocultava i el cordó de set estrelles que indicava el lloc on estava soterrada (Fig. 8). Seguí el gravador, tot i que amb més fidelitat a la imatge original, el quadre que Agostí de Ridaura n'havia pintat per a la catedral de València a les darreries del segle XVII (Fig. 9).

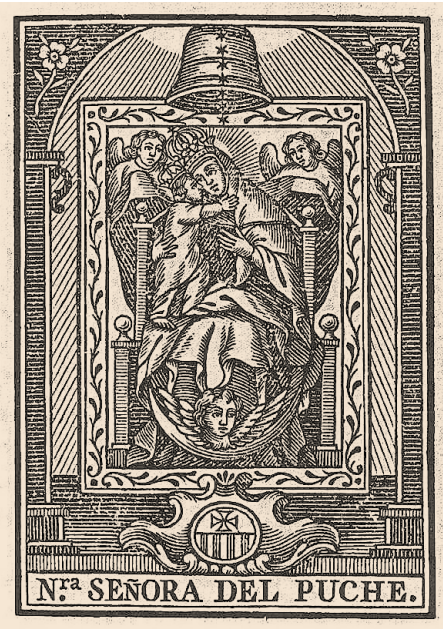

Fig. 8. Autor desconegut (1780 ca.) Nuestra Señora del Puche, xilografia, repertori de la impremta Laborda, València.

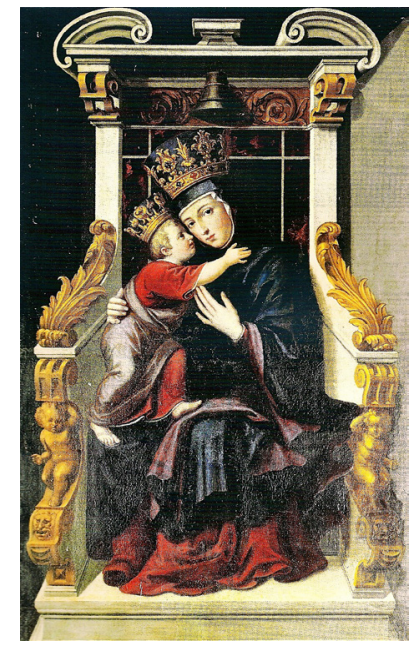

Fig. 9. Ridaura, A. de (darreries del segle XVII) Nostra Senyora del Puig, oli sobre llenç, $129 \mathrm{x}$ $86,5 \mathrm{~cm}$., València, catedral.

36 Gozos a Nuestra Señora del Puche, s. 1l., s. i., s. a. [València, Agustín Laborda o viuda de Laborda, entre 1755-1808], Universitat de València, BH Ms. 0870 (08). 
Joan Carles Gomis Corell. Històries escrites, històries cantades i històries pintades. Els goigs en el Barroc valencià

La llegenda fundacional de la Mare de Déu del Puig, imatge de gran significació per ésser institució reial del moment de la conquesta, serví de model a diverses altres que, només variant-ne alguns detalls narratius, també es presentaren com a imatges soterrades quan la invasió sarraïna per a evitar llur destrucció i segles després trobades pels nous pobladors cristians. S'escrigueren també aquestes llegendes en els respectius goigs, els quals, en estampar-se, s'il lustraren amb imatges conceptuals que seguiren el model d'Agustí de Ridaura. La Mare de Déu de la Misericòrdia de Borriana n'és una. El títol dels seus goigs ja explica l'argument central -«(...) trobada per uns pastors en un estanch del riu Anna (...) baix de una campana (...)»-, i la xilografia que n'encapçala el full de l'estampació conceptualment així ho representa (Fig. 10). ${ }^{37}$

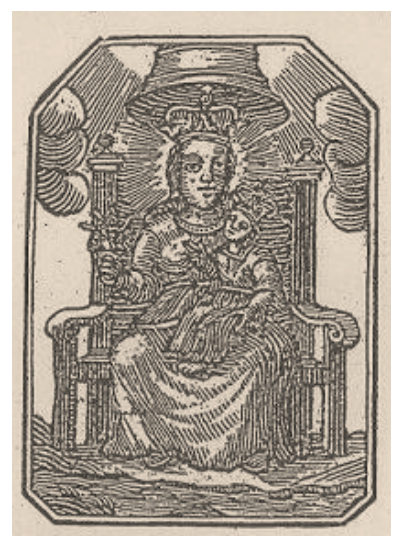

Fig. 10. Autor desconegut (1750 ca.) Mare de Déu de la Misericòrdia de Borriana, xilografia.

Uns altres casos són la Mare de Déu de l'Olivar d'Alaquàs i la de la Salut de Xirivella; els fulls dels seus goigs també s'il lustren amb sengles imatges sobre les quals hi ha una campana, convertida en atribut iconogràfic (Gomis Corell 2002: 57-64; 2003b: 134-141). La semblança més clara amb la llegenda de la Mare de Déu del Puig és, però, la de la imatge de la Mare de Déu del Do d'Alfafar. Segons escriu Dolz de Castelar (1668/1733: IV, 399), fou instituïda per Jaume I en acció de gràcies per la conquesta d'Alzira. Posteriorment, aquesta pretesa narració històrica va estar enriquida amb detalls llegendaris i anecdòtics per a fer-la més admirable i atorgar a la imatge una antiguitat que la duguera, com la del Puig, a l'època anterior a la invasió musulmana. No sols el rei, estant acampat en el «(...) llano que hay entre Alfafar y el camino (...)» d'Alzira, sentí el toc d'una campana i decidí dedicar el lloc a la Mare de Déu,

37 Llaor a la imatge de la Mare de Déu de la Misericòrdia, trobada per uns pastors (...) quant la campana major de la església parroquial de dita vila tocava al alçar a Déu, s. 1l., s. i., s. a. [València, ca. 1750]. 
Joan Carles Gomis Corell. Històries escrites, històries cantades i històries pintades. Els goigs en el Barroc valencià

com diu Dolz de Castelar, sinó que la campana estava soterrada allí mateix, unes estrelles que caïen del cel n'assenyalaren el lloc exacte i, en desenterrar-la, hi trobaren la imatge dins una pila baptismal. Aquesta llegenda s'escrigué als primers goigs coneguts d'aquesta invocació, al full dels quals, de mitjan segle XVIII (vid. nota 12), s'estampà una imatge conceptual que, en situar la imatge damunt la pila i dur la campana a sobre, s'associa amb la invocació, tot i ser-ne l'original una imatge sedent (Fig. 11).

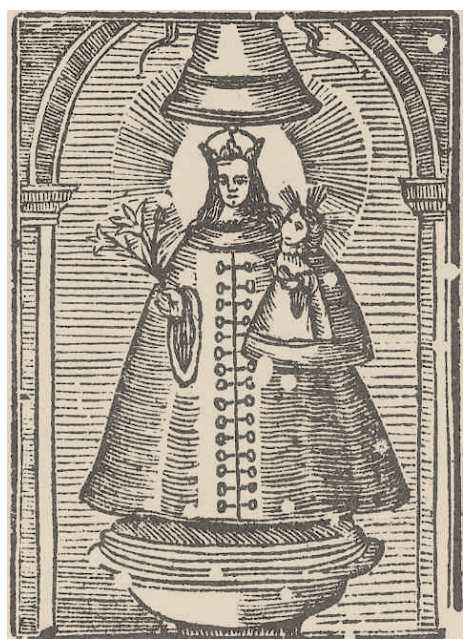

Fig. 11. Autor desconegut (1725-1765), Nostra Senyora del Do, d'Alfafar, xilografia, repertori de la impremta d'Onofre Garcia, València.

Posteriorment, en paral lel al perfeccionament de les tècniques del gravat, aquesta llegenda va estar interpretada visualment en la xilografia que encapçala tres estampacions d'un segon text de goigs dedicats aquesta advocació: representa el moment que, desenterrada la campana, troben la imatge, sedent, com l'original, dins la pila baptismal en presència del rei en Jaume. Els detalls narratius i descriptius són abundants: el cordó d'estrelles que cau del cel, les tendes del campament militar, els soldats, llances, armadures, les eines amb què han desenterrat la imatge, i fins i tot el batall de la campana, per tal de recrear visualment la sonoritat del moment (Fig. 12). ${ }^{38}$

38 Gozos a Nuestra Senñora del Don, venerada en el lugar de Alfafar, s. 11., s. i., s. a. [València, Impremta de Laborda, darrer quart del segle XVIII], a Ferri Chulio (1988: f. solt); cf. Gozos a Nuestra Señora del Don, venerada en el lugar de Alfafar, Valencia, Pascual M. Villalba, s. a., a Ferri Chulio (1988: f. solt). 


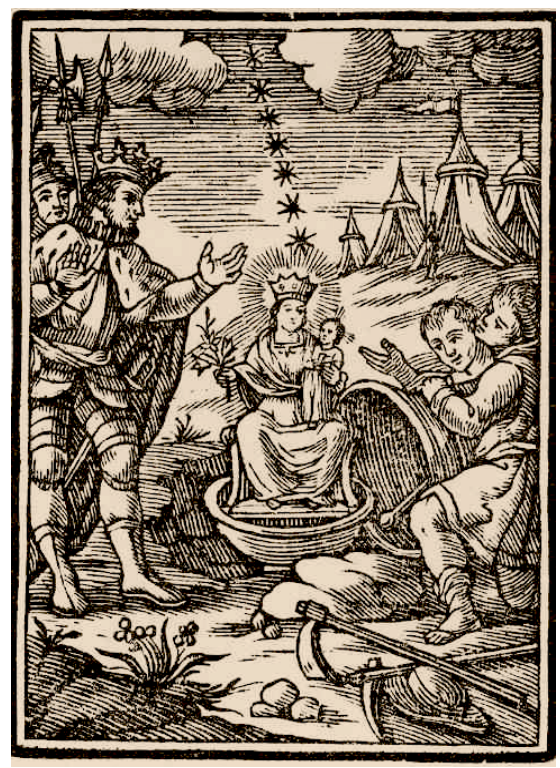

Fig. 12. Autor desconegut, Troballa de la imatge de la Mare de Déu del Do en presència de Jaume I, xilografia, 1770 ca., repertori de la impremta Laborda, València.

Diverses altres imatges narratives estampades en fulls de goigs podrien presentar-se ara i ací: la de la troballa del Crist de Sumacàrcer, la del Crist del Rescat del Convent d'agostines de Santa Tecla de la ciutat de València, les escenes de caritat de sant Tomàs de Villanueva, etc. Definitivament, les històries escrites i cantades pels goigs es narraven també en imatges. El full de l'estampació, suport material dels goigs -el «cos dels goigs», l'anomena De Courcelles (2008: 241)-, feia simultàniament present la història en diversos codis.

\section{Cloenda}

Les conseqüències tan beneficioses que per a la creació i difusió literàries tingué la invenció de la impremta són ben conegudes. Els goigs també se'n beneficiaren, però la difusió i l'èxit i d'aquestes composicions fins a convertir-se en un dels gèneres més consumits pels segments majoritaris de la societat -en el sentit esmentat, com ja plantejà Palàcios (1977: III, 13), podrien considerarse populars- no sols foren conseqüència d'aquell invent. La impremta, efectivament, en permeté tirades abundants i barates; facilità la reproducció del text -ço és, dels continguts conceptuals de l'oració pròpiament dita-, però sobretot facilità la traducció icònica d'aquells continguts, la qual cosa augmentà la possibilitat de comprensió per les persones no lletrades, assegurant-ne el record col lectiu. El suport -o component- matèric dels goigs, el full d'estampació, es convertí 
Joan Carles Gomis Corell. Històries escrites, històries cantades i històries pintades. Els goigs en el Barroc valencià

en transsumpte de la imatge del personatge celestial al qual anaven adreçades. Associava oració i destinatari. Igualment determinant, fou que feren servir el component essencial i indispensable de l'oració cristiana: el cant i, amb ell, l'oralitat, la comunicació a través de la paraula pronunciada i escoltada en públic, la qual el Barroc, tot i els extraordinaris efectes de la impremta, sabé canalitzar a través d'esdeveniments rellevants de gran repercussió social: la predicació, el teatre i les lectures i declamacions en veu alta. En els goigs, a més, la paraula era proclamada, ja que la forma específica de la dansa trobadoresca permetia participar conjuntament en el cant. Quedaven els goigs, consegüentment, integrats en el sistema narratiu tan desitjat pel Barroc: text narratiu, narració pronunciada i escoltada i narració vista, amb un valor didàctic que pressuposava la participació dels receptors. 
Joan Carles Gomis Corell. Històries escrites, històries cantades i històries pintades. Els goigs en el Barroc valencià

\section{Bibliografia}

Alberti, L. B. (1474 [1966]) L'architettura [De re aedificatoria], Milano, Il Polifilo.

Ares, A. (1640) Discurso del ilustre origen y grandes excelencias de la misteriosa imagen de Nuestra Señora de la Soledad del convento de la Victoria de Madrid de la... Orden de los Minimos de san Francisco de Paula, Madrid, Pedro Taço.

Association Départamentale pour le Déveloplment Musical des Pyrénées-Orientales, Institució Musical Popular d'Europa Mediterrània de Colliure (1996) Goigs du diocèse d'Elne Perpignan / de la diòcesi d'Elna Perpinyà, Centre Internacional de Música Popular.

Ballús i Casòliva, G., Ezquerro Esteban, A. (2013) «La primera edición conocida de gozos polifónicos a la manera de las hojas volantes (Barcelona, 1702)», Revista Catalana de Musicologia, VI, pp. 83-111.

Batlle, J. B. (1924) Los goigs a Catalunya. Breus consideracions sobre son origen y sa influència en la poesia mística popular, Barcelona, L'Arxiu.

- (1925) Los goigs a Catalunya en lo segle XVIII. Recull d'estudis critichs amb un centenar de facsimils..., Barcelona, Tipografia Catòlica.

Benach i Torrents, M. (1961/2005) La devoció popular a sant Ramon de Penyafort, Tarragona, El Medol.

Breva i Franch, F. (2013), Sant Antoni de Betxí, Betxí, Ajuntament de Betxí.

Brudieu, J. (2005) Madrigal I. Goigs de Nostra Dona, a cura de Casas, J., Barcelona, DINSIC Publicacions Musicals.

Cardona i Roig, O. (1990) La tradició literària $i$ els goigs de sant Ramon de Penyafort, Vilafranca del Penedès, Museu de Vilafranca.

Caro Baroja, J. (1985) Las formas complejas de la vida religiosa. Religión, sociedad y carácter en la España de los siglos XVI y XVII, Madrid, Sarpe.

Cerone, Pietro (1613) El melopeo y maestro: Tractado de música theórica y práctica...: repartido en XXII Libros..., Nápoles, Juan Bautista Garbano y Lucrecio Nucci.

Cervera, J. (1707) Las tres púrpuras de Alzira, Bernardo, María y Gracia. Vida y martirio de los tres santos hermanos, posesión, manutención y promoción del culto que han tenido [...], Valencia, Jaime Bordázar.

Christian, W. A. (1991) Religiosidad local en la España de Felipe II, Madrid, Nerea.

Climent, J. (1979) Fondos musicales de la Región Valenciana. I. Catedral Metropolitana de Valencia, Valencia, Instituto de Musicología, Institución Alfonso el Magnánimo, Diputación Provincial de Valencia.

Combes, B. (1714),Feliz hallazgo del más rico y celestial tesoro, María Santíssima, aplaudida en su peregrina imagen [de] Nuestra Señora de Campanar..., Valencia, Vicente Cabrera.

De Cobarruvias, S. (1611) Tesoro de la lengua castellana o española, Madrid, Luis Sánchez. 
Joan Carles Gomis Corell. Històries escrites, històries cantades i històries pintades. Els goigs en el Barroc valencià

De Courcelles, D. (2008) La paraula de l'àngel. Una aproximació plural als goigs, Barcelona, Fragmenta Editorial.

- (2017) «Goigs del Roser i Goigs a Carles tercer: el fracàs d'un art del poder», Viatge per la bistòria i la literatura de les terres catalanes, Alacant, Institut Interuniversitari de Filologia Valenciana, Universitat d'Alacant.

De la Justicia, J. (1664) Historia de la Virgen de la Cueva Santa. Escriviola el padre Josef de la Justicia, de la Compañia de Jesús. Publicala el doctor Josef Martí, prepósito del santuario. Dedicada a la reyna..., Valencia, Francisco Ciprés.

De Ribera, J. (1594) Synodus diocesana Valentina, celebrata prae... València, Álvaro Franco.

Dolz de Castelar, E. (1684) Año virgíneo, cuios días son finezas de la gran reyna del cielo, María Santíssima [...] sucedidas aquel mismo día en que se refieren: añádense a estas trescientos y sesenta y seys exemplos, con otras tantas exortaciones, oraciones [...], Valencia, Vicente Cabrera, a costa de Francisco Agrait Mercader, 1686 (Madrid: Bernardo Peralta, 1733).

Escartí, V. J. (2005) Pere Esteve i Puig. Escrits valencians, València, Institució Alfons el Magnànim, Diputació de València.

Ettinghausen, H. (1999) «De la noticia a la prensa (san Raimundo de Peñafort, Barcelona, 1601)», en Strosetzki, C. (coord.), Actas del V Congreso Internacional de la Asociación Internacional Siglo de Oro. Münster, 20-24 de julio de 1999, Vervuert, Iberoamericana, pp. 490-502.

Fernández de la Cuesta, I. (2002) «Sobre el discanto y el repertorio polifónico de Notre Dame de París, siglos XII y XIII», en Crawford, D. (coord.), Enconium musicae: essays in memory of Robert J. Snow, Hillsdale, New York Pendragon Press, pp. 561-576.

Ferri Chulio, A. de Sales (1988) Los gozos a Santa María del Don, patrona de Alfafar, s. ll., s. i.

Fiorentino, G. (2014) «Canto llano, canto de órgano y contrapunto improvisado: el currículo de un músico profesional en la España del Renacimiento», en García Pérez, A. / Otaola González, P. (coords.), Francisco de Salinas [Recurso electrónico]: música, teoría y matemática en el Renacimiento, Salamanca, Ediciones Universidad de Salamanca.

Fuster, J. P. (1827) Biblioteca valenciana de los escritores que florecieron hasta nuestros días. Con adiciones y enmiendas a la de don Vicente Ximeno. Tomo I. Contiene los autores hasta 1700, Valencia, José Ximeno.

García de Caralps, J. (1617) Historia de san Oleguer, arçobispo de Tarragona y obispo de Barcelona. Escrivense en ella su vida, milagros y excellencias, muchos loores de Cathaluña, con las historias de importancia que acaecieron en su tiempo (...), Barcelona, Sebastián Matevad.

Genovés y Olmos, E. (1911) Catàlech descriptiu de les obres impreses en llengua valenciana, València, Manuel Pau.

Gómez, V. (1602) Relación de las famosas fiestas que bizo la ciudad de Valencia a la canonización del bienaventurado san Raymundo de Penyafort, en el convento de predicadores, Valencia, Juan Crisóstomo Garriz, a costa de Gaspar Mançano. 
Joan Carles Gomis Corell. Històries escrites, històries cantades i històries pintades. Els goigs en el Barroc valencià

Gomis Corell, J. C. (1993) «Dues melodies tradicionals de gojos al Camp de Morvedre», Braçal. Revista d'Estudis del Camp de Morvedre, 7, pp. 37-53.

(1996) «Els "Gozos al santísimo Cristo de la Sangre” i els "Gozos al ínclito y glorioso mártir san Sebastián” de Polinyà de Xúquer», Al-Gezira, 9, pp. 479-503.

- (1999a) «Joan Baptista Comes i les formes de la música tradicional valenciana. Estudi historicomusical dels Gozos del Real Colegio de Corpus Christi», en Escartí, V. J., Cabanilles i el Barroc valencià. Actes de les II Jornades Culturals, Algemesí, Saó, pp. 187-195.

(1999b) «Una estructura culta para un género tradicional: los gozos de Joan Baptista Comes. Su influencia en la tradición musical valenciana», en Sánchez Erquicia, C. J. (ed.), Actas del IV Congreso de la Sociedad Ibérica de Etnomusicología. Granada, 9-12 julio 1998, [Pamplona], Sociedad Ibérica de Etnomusicología, pp. 171-195.

- (2002) «Imatge, poesia i música al voltat de la Mare de Déu de l’Olivar d'Alaquàs: el full dels Gozos a Nuestra Señora del Olivar, que està en su convento de Alaquás», Ars Longa. Cuadernos de Arte, 11, pp. 57-64.

- (2003a) «Els fulls del gojos de la Mare de Déu del Castell de Cullera conservats en la col lecció de la Universitat de València», en IV Jornades d'Estudis de Cullera. Cullera, 26, 27 i 28 de novembre de 1999, Benicull de Xúquer, 7 i mig, pp. 67-87.

—. (2003b) «Els gojos marians de l'Horta Sud recollits per Marc Antoni d'Orellana. La seua pervivència actual», Torrens. Estudis $i$ investigacions de Torrent $i$ comarca, 15, pp. 134-141.

- (2010) «Els goigs de la Mare de Déu del Do d'Alfafar: l'expressió cultural de la devoció mariana mitjançant la música, la poesia i la imatge», Memòria d'Alfafar, Alfafar, Associació d'Estudis d'Alfafar, pp. 143-169.

- (2013) «Docere et delectare: poesia, música i imatge devocionals en defensa de la religiositat contrareformista al darrer barroc balencià», eHUmanista/IVITRA 3, pp. 258-271.

Huglo M. (2005) La théorie de la musique antique et médiévale, Ashgate, Aldershot / Burlintong, IV.

Libro de la Donación, Concordias, Privilegios, Sentencia, Invención de la Virgen y Censos. También está la Bula de Clemente 6 de Privilegio de Diezmos, Arxiu del Regne de València, Secció Clero, Llibre 3886.

López de Ayala, I. (1787) El Sacrosanto y Ecuménico Concilio de Trento, traducido al idioma castellano [...], Madrid, Imprenta Real.

Meneu i Gaya, A. (1995) «Els Gojos a sant Antoni de Betxí», Butlletí d'Informació Municipal, especial sant Antoni 95.

Mercader, C. (1677) Vida admirable del siervo de Dios fray Pedro Esteve [...], Valencia, Francisco Mestre.

Nassarre, P. (1723) Segunda parte de la Escuela de Música, que contiene cuatro libros. El primero trata de todas las especies (...) El segundo, de variedad de contrapuntos (...), Zaragoza, Manuel Román. 
Joan Carles Gomis Corell. Històries escrites, històries cantades i històries pintades. Els goigs en el Barroc valencià

Ortí, M. A. (1659) Solenidad festiva con que en la insigne, noble, lealy coronada ciudad de Valencia se celebró la feliz. nueva de la canonización de su milagroso arcobispo santo Tomás de Villanueva, Valencia, Gerónimo Vilagrasa

Ortí y Mayor, J. V. (1731) Vida, virtudes, milagros y festivos cultos de santo Thomás de Villanueva, arzobispo de Valencia, de la orden de nuestro gran padre san Agustín, Valencia, Juan González.

- (1750) Pasmosa vida, virtudes y milagros del venerable padre fra Gaspar de Bono, provincial de los minimos de la provincia de Valencia, Valencia, Josep Tomàs Lucas.

Palacios, J. (1977) Poesia religiosa del segle XVI, València, Editorial l'Estel /Fundació Ausiàs March.

Pérez, T. (1748) Compendio del feliz, hallazgo de la milagrosissima imagen de la Virgen de Aguas Vivas, con alguna reflexión de sus notables circunstancias [...], Valencia, Viuda de Gerónimo Conejos (Carcaixent, 2007).

Prades, J. (1596) Historia de la adoración y uso de las santas imágenes, y de la imagen de la Fuente de la Salud, Valencia, Felipe Mey.

Preciado, D. (1979) «Qué son las “varillas” o “varetas” musicales», Revista de Musicología, II, 2, pp. 345-347.

Puiggari, M. P. (recop.) (1897) Los Goigs dels ous [...] et précédés d'une notice bistòriques de B. Alart et suivis de la musique des Goigs et Cantarelles, Perpignan, Charles Latrobe.

Puig Torralba, J. M. / Martí Grajales, F. (1883) Estudio bistórico-crítico de los poetas valencianos de los siglos XVI, XVII y XVIII, Valencia, Viuda de Ayoldi.

Ribelles Comín, J. (1969) Bibliografía de la lengua valenciana: o sea catálogo razonado por orden alfabético de autores de los libros folletos, obras dramáticas, periódicos, coloquios, coplas, chistes, discursos, romances, alocuciones, cantares, gozos, etc., que escritos en lengua valenciana y bilingüe, II, Nendeln/Liechtenstein, Kraus Reprint [Madrid: Revista de Archivos, Bibliotecas y Museos, 1929].

. (1939) Bibliografía de la lengua valenciana [...], III, Madrid, Revista de Archivos, Bibliotecas y Museos.

Rodríguez, J. (1747) Biblioteca valentina, Valencia, José Tomás Lucas.

Seguí, S. (1973) Cancionero musical de la provincia de Alicante, Alicante, Diputación Provincial de Alicante

- (1980) Cancionero musical de la provincia de Valencia, Valencia, Institución Alfonso el Magnánimo, Diputación Provincial de Valencia.

- (1990) Cancionero musical de la provincia de Castellón, Segorbe, Caja Segorbe/Caja de Valencia/ Fundación Caja Segorbe.

Selva, P. (1702) Maravillas del poder divino, en el Santísimo Christo de Sumacárcel, de el Reyno de Valencia: antiquisimo solar de la Nobilíssima Casa de los Señores Crespies de Valdaura, Condes de Sumacárcel, Valencia, Diego de Vega. 
Joan Carles Gomis Corell. Històries escrites, històries cantades i històries pintades. Els goigs en el Barroc valencià

Tatarkiewich, W. (1976/1997) Historia de seis ideas. Arte, forma, creatividad, mímesis, experiencia estética, Madrid, Tecnos.

Tosca, T. (1727) Compendio mathemático, en que se contienen todas las materias más principales de las ciencias que tratan de la cantidad. Tomo II, Madrid, Antonio Marín [Valencia, Antonio Bordazar, 1709].

Trellat sumàriament fet de la bulla o confraria del Psaltiri o Roser, e cobles a lahor e glòria de la sacratíssima e intemerada Verge Maria del Roser, València, s. i., 1546.

Vidal y Micó, F. (1735) Historia de la portentosa vida y milagros del valenciano apóstol de Europa san Vicente Ferrer, Valencia, Estevan Dolz.

Villanueva, J. (1902) Viaje literario a las iglesias de España, II, Madrid, Imprenta de Fortanet.

Ximeno, V. (1747) Escritores del Reyno de Valencia (...), Valencia, José Estevan Dolz. 